\title{
Hypomethylation and up-regulation of $P D-1$ in $T$ cells by azacytidine in MDS/AML patients: A rationale for combined targeting of PD-1 and DNA methylation
}

\author{
Andreas D. Ørskov ${ }^{1, *}$, Marianne B. Treppendahl ${ }^{1, *}$, Anni Skovbo ${ }^{2,3}$, Mette S. Holm ${ }^{4}$, \\ Lone S. Friis ${ }^{1,5}$, Marianne Hokland ${ }^{2}$, Kirsten Grønbæk ${ }^{1}$ \\ ${ }^{1}$ Department of Hematology, Rigshospitalet, Copenhagen University Hospital, Copenhagen, Denmark \\ ${ }^{2}$ Department of Biomedicine, Aarhus University, Aarhus, Denmark \\ ${ }^{3}$ FACS Core Facility, Aarhus University, Aarhus, Denmark \\ ${ }^{4}$ Department of Hematology, Aarhus University Hospital, Aarhus, Denmark \\ ${ }^{5}$ Department of Hematology, Odense University Hospital, Odense, Denmark \\ *These authors have contributed equally to this work \\ Correspondence to: \\ Kirsten Grønbæk, e-mail: kirsten.groenbaek@regionh.dk \\ Keywords: myelodysplastic syndromes, hypomethylating agents, DNA methylation, programmed death-1, T cells \\ Received: November 29, $2014 \quad$ Accepted: February 09, $2015 \quad$ Published: March 18, 2015
}

\section{ABSTRACT}

The hypomethylating agents (HMAs) are standard therapy for patients with higher-risk myelodysplastic syndrome (MDS); however, the majority of the patients will lose their response to HMAs over time due to unknown mechanisms. It has recently been shown that $\mathrm{T}$ cell expression of the immunoinhibitory receptor PD-1 is regulated by DNA methylation. In 12 of 27 patients (44\%) PD-1 promoter demethylation was observed in sorted peripheral blood $\mathrm{T}$ cells isolated over consecutive cycles of treatment with 5-azacytidine (5-aza). The PD-1 promoter demethylation correlated with an increase in PD-1 expression. Moreover, demethylation of the PD-1 promoter correlated with a significantly worse overall response rate $(8 \% \mathrm{vs} .60 \%, p=0.014)$, and a trend towards a shorter overall survival $(p=0.11)$ was observed. A significantly higher baseline methylation level of the PD-1 promoter was observed in T cells of non-responding patients compared to healthy controls $(p=0.023)$.

Accordingly, in addition to their beneficial function, HMAs induce PD-1 expression on $T$ cells in the MDS microenvironment, thereby likely hampering the immune response against the MDS blasts. Thus, we suggest that activation of the PD-1 checkpoint during HMA treatment can be a possible resistance mechanism, which may be overcome by combination therapy with a PD-1 pathway inhibitor.

\section{INTRODUCTION}

Myelodysplastic syndromes (MDS) are clonal hematopoietic stem cell disorders, characterized by increased proliferation and aberrant differentiation combined with a high rate of apoptosis [1]. This results in ineffective hematopoiesis and peripheral blood cytopenias as well as an increased risk of developing acute myeloid leukemia (AML). Compared to conventional care regimens, hypomethylating agents (HMAs) have resulted in improved outcomes in MDS [2-4], including delayed leukemic transformation [4] and prolonged survival in patients with higher-risk MDS [2]. 5-azacytidine (5-aza) treatment has also prolonged overall survival (OS) in patients with AML with $20-30 \%$ bone marrow blasts [5], and decitabine (5-aza-2'deoxycytidine) has improved the response rates in older patients $(>65 \mathrm{yrs})$ with newly diagnosed AML [6]. In addition, HMAs are also approved by the U.S Food and Drug Administration and the European Medicines Agency for treatment of chronic myelomonocytic leukemia (CMML). Still, only about 50\% of the HMA treated patients achieve a clinical response, the majority will lose response over time [2], and the outcome after HMA failure is poor with a median survival of only 
5.6 months [7]. Consequently, there is an urgent need for efficient new treatment modalities in MDS.

The molecular mechanisms of action of HMAs are currently not completely understood. Reactivation of silenced tumor suppressor genes has been suggested to be a key event [8]; however, others and we have also shown that HMAs induce the expression of tumor antigens such as cancer testis antigens (CTAs) on the malignant cells [9, 10]. Since CTAs are normally only expressed at immune privileged sites, e.g. in testicular germ cells, expression of CTAs by the MDS blasts can stimulate an anti-tumor immune response by induction of effector $\mathrm{T}$ cells of the adaptive immune system [11-13]. By contrast, the mechanisms of resistance to HMAs are largely unknown.

The programmed death-1 (PD-1) is an immunoinhibitory receptor mainly expressed on activated $\mathrm{T}$ cells [14]. Two ligands for PD-1 are currently known, PD-L1 (B7-H1) and PD-L2 (B7-DC). Under normal circumstances both ligands are expressed in low levels in a wide variety of cell types, but surface expression of the protein is rare [15]. The major role of PD-1 is to limit T cell effector responses in peripheral tissues in relation to infection and inflammation, and to limit autoimmunity [14, 16]. In addition, the PD-1/PD-L1 pathway plays an important role in tumor immune evasion and growth [17]. Interestingly, it was recently shown that expression of PD-1 on T cells is regulated by DNA methylation [18]. Hypomethylation of the $P D-1$ promoter was observed in $\mathrm{CD}^{+} \mathrm{T}$ cells with inhibited function, referred to as exhausted T cells. Interestingly, in vitro studies showed that treatment with an HMA increases the expression of PD-1 on activated T cells [18].

PD-L1 and, to a lesser extent, PD-L2 are overexpressed in various types of human tumors, including hematological malignancies such as MDS and AML [19-23]. An increasing amount of data indicate that interactions between PD-1 and its ligands are important mechanisms of immune suppression in the tumor microenvironment $[15,19,20]$.

The objective of this study was to investigate the in vivo effect of HMA on $P D-1$ methylation and expression in $T$ cells obtained from patients during 5-aza treatment, and to evaluate the rationale of combining HMA with a PD-1 pathway inhibitor in MDS.

\section{RESULTS}

\section{PD-1 methylation in healthy individuals}

First, we evaluated the level of $P D-1$ promoter methylation in peripheral blood mononuclear cells (PBMNCs), granulocytes, $\mathrm{CD}^{+} \mathrm{T}$ cells, $\mathrm{CD}^{+} \mathrm{T}$ cells, $\mathrm{CD}^{+} \mathrm{T}$ cells, and $\mathrm{CD} 19^{+} \mathrm{B}$ cells from five healthy donors (Figure 1). The mean $P D-1$ methylation level was: PBMNCs $37.2 \%$ (range 24.9-58.7), granulocytes $60.1 \%$ (range 47.3-77.5), $\mathrm{CD}^{+} \mathrm{T}$ cells $20.2 \%$ (range, 9.7-33.2), $\mathrm{CD}^{+} \mathrm{T}$ cells $24.9 \%$ (range 11.6-38.5), $\mathrm{CD}^{+} \mathrm{T}$ cells $24.0 \%$ (range $12.8-46.0$ ) and $\mathrm{CD} 19^{+} \mathrm{B}$ cells $43.3 \%$ (range

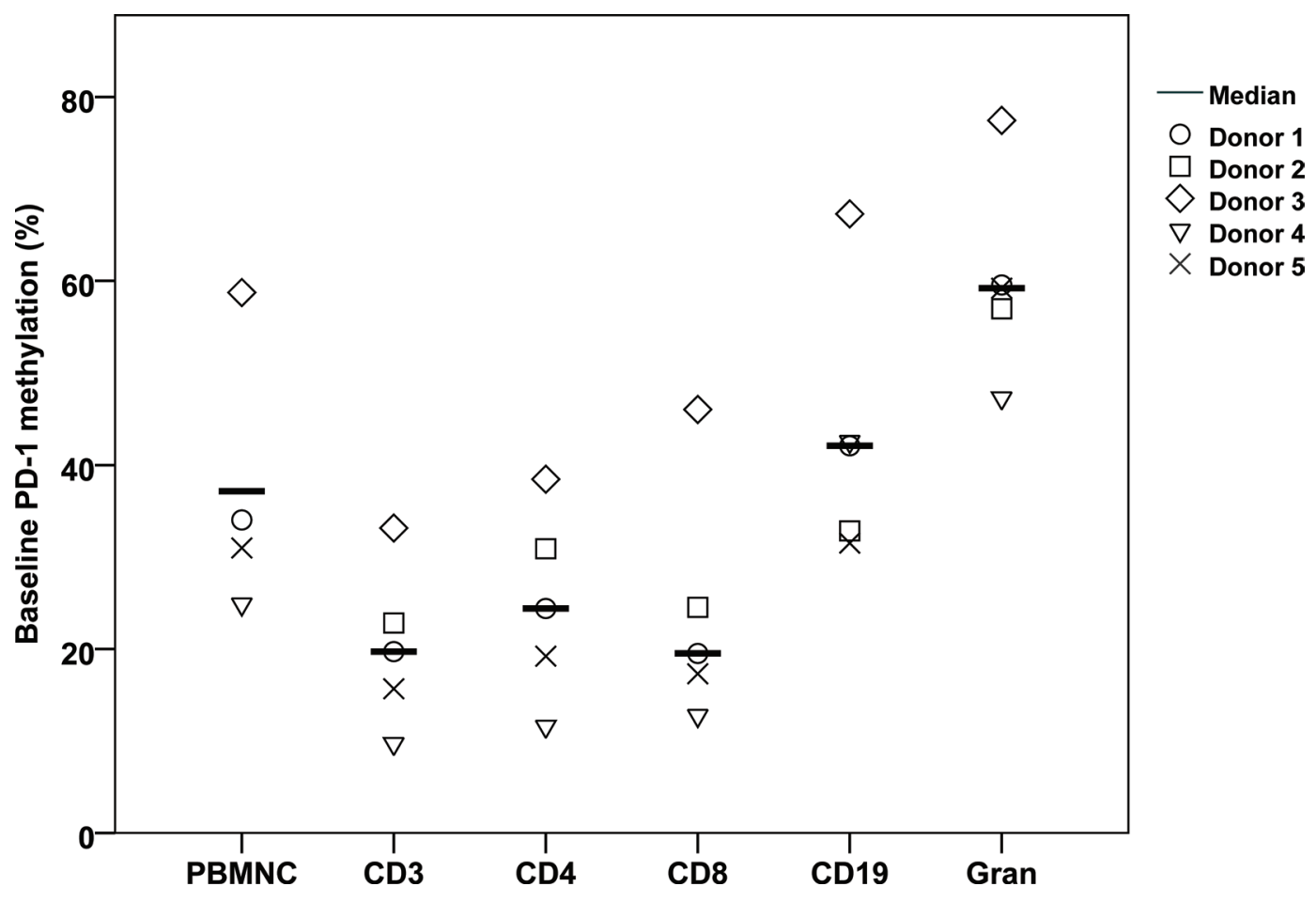

Figure 1: Mean $P D-1$ promoter methylation in six distinct cell populations from 5 healthy donors. All cells are from peripheral blood. The graph shows the means. $\mathrm{PBMNC}=$ peripheral blood mononuclear cells. $\mathrm{CD} 3=\mathrm{CD} 3^{+} \mathrm{T}$ cells. $\mathrm{CD}=\mathrm{CD} 4{ }^{+} \mathrm{T}$ cells. $\mathrm{CD} 8=\mathrm{CD}^{+} \mathrm{T}$ cells. Gran $=$ granulocytes. $\mathrm{B}$ cells $=\mathrm{CD} 19^{+} \mathrm{B}$ cells. 
31.5-67.3). The analyses revealed a varying methylation level both among the different cell types and donors. The $\mathrm{T}$ cell population carried the lowest level of $P D-1$ promoter methylation, which is in line with the fact that the highest $P D-1$ gene expression is observed in T cells.

\section{PD-1 methylation in peripheral blood mononuclear cells from 5-aza treated patients}

Next, we investigated the status of $P D-1$ promoter methylation in PBMNCs sampled from patients during the course of 5-aza treatment. Initially, we analyzed unsorted PBMNCs from 15 (12 MDS, 1 AML and 2 CMML) 5-aza treated patients (patient characteristics, see Table 1). Samples from day one and day five of each treatment cycle were analyzed. The patients had received a median number of four cycles of 5-aza (range 2-13). A total of 121 peripheral blood (PB) samples were analyzed. Nine of 15 $(60 \%)$ patients demonstrated a significant decrease in $P D-1$ promoter methylation after 5-aza administration compared to the pre-treatment level (Figure 2A). Demethylation was defined relative to the baseline methylation level based on the following criteria: A statistically significant decrease in methylation level and a decrease of $\geq 10 \%$-points. The demethylation should furthermore occur in $\geq 2$ distinct treatment cycles.
We observed that the baseline level as well as the continuous level of $P D-1$ promoter methylation varied among the patients during 5-aza treatment with different methylation patterns over time. In nine patients $P D-1$ promoter demethylation was observed, mostly followed by a diverse remethylation just before the start of the next cycle. In the remaining six patients a stable methylation level, or a slight gain in methylation, was seen throughout the entire treatment period (Figure 2B). The mean baseline methylation level was significantly higher in the group of patients in whom we observed a demethylation of the $P D-1$ promoter, $57.0 \%$ (SD, 16.2) vs. $30.4 \%$ (SD, 15.0), $p=0.007,95 \%$-CI $[8.7 ; 44.5]$. Taken together, these results reveal that 5-aza does demethylate the $P D-1$ promoter in patients PBMNCs in vivo.

\section{PD-1 promoter methylation in $\mathrm{CD4}^{+}$and $\mathrm{CD8}^{+}$ $T$ cells from 5-aza treated patients}

Since the observed changes in methylation level in PBMNCs could either be a result of a real change in methylation or simply a result of an alteration in the composition of the mononuclear cell subpopulations, we extended our analyses to include isolated $\mathrm{T}$ lymphocyte subsets. In 22 (15 MDS, 4 AML, 3 CMML, patient characteristics see Table 1) of the 27 patients we

Table 1: Patient characteristics RA $=$ refractory anemia. $\mathrm{RCMD}=$ refractory cytopenias with multilineage dysplasia. $\mathrm{RAEB}=$ refractory anemia with excess blasts. $\mathrm{AML}=$ acute myeloid leukemia. $\mathrm{CMML}=$ chronic myelomonocytic leukemia. IPSS $=$ international prognostic scoring system. $\mathrm{IWG}=$ International Working Group. $\mathrm{CR}=$ complete remission. 5 -aza $=5$-azacytidine.

\begin{tabular}{|c|c|c|c|c|}
\hline & All & PD-1 demethylation & $\begin{array}{c}\text { No PD-1 } \\
\text { demethylation }\end{array}$ & $p$ value \\
\hline $\mathbf{N}$ & 27 & $12(44 \%)$ & $15(56 \%)$ & \\
\hline Age median (range) & $65(46-82)$ & $67(52-82)$ & $66(46-77)$ & .79 \\
\hline \multicolumn{5}{|l|}{ Sex } \\
\hline Male & 14 & 6 & 8 & .86 \\
\hline Female & 13 & 6 & 7 & \\
\hline \multicolumn{5}{|l|}{ WHO diagnosis } \\
\hline RA & 2 & 0 & 2 & .49 \\
\hline RCMD & 3 & 1 & 2 & 1 \\
\hline RAEB-1 & 2 & 0 & 2 & .49 \\
\hline RAEB-2 & 12 & 6 & 6 & .60 \\
\hline AML & 5 & 4 & 1 & .14 \\
\hline CMML-2 & 3 & 1 & 2 & 1 \\
\hline \multicolumn{5}{|l|}{ IPSS } \\
\hline Low & 0 & 0 & 0 & - \\
\hline Int-1 & 7 & 1 & 6 & .091 \\
\hline
\end{tabular}

(Continued) 


\begin{tabular}{|c|c|c|c|c|}
\hline & All & PD-1 demethylation & $\begin{array}{c}\text { No } P D-1 \\
\text { demethylation }\end{array}$ & $p$ value \\
\hline Int-2 & 9 & 6 & 3 & .13 \\
\hline High & 9 & 4 & 5 & 1 \\
\hline AML (>30\% blasts) & 1 & 1 & 0 & - \\
\hline Missing & 1 & 0 & 1 & - \\
\hline \multicolumn{5}{|l|}{ Cytogenetics (IPSS) } \\
\hline Good & 8 & 2 & 6 & .24 \\
\hline Intermediate & 10 & 4 & 6 & 1 \\
\hline Poor & 9 & 6 & 3 & .11 \\
\hline Prior treatment & 16 & 6 & 10 & .45 \\
\hline Chemotherapy & 8 & 6 & 5 & \\
\hline Growth factor treatment & 8 & 1 & 7 & \\
\hline No prior treatment & 11 & 6 & 5 & \\
\hline $\begin{array}{l}\text { Time (months) from } \\
\text { diagnosis until 5-aza-start } \\
\text { median (range) }\end{array}$ & $4(0-37)$ & $6.5(0-11)$ & $3(0-37)$ & .83 \\
\hline $\begin{array}{l}\text { Median no. of cycles of } \\
\text { 5-aza }\end{array}$ & $5(2-14)$ & $4(2-13)$ & $5(3-14)$ & .40 \\
\hline \multicolumn{5}{|l|}{ IWG 2006 Response } \\
\hline $\mathrm{CR}$ & $3(11 \%)$ & $1(8 \%)$ & $2(13 \%)$ & 1 \\
\hline Overall response & $10(37 \%)$ & $1(8 \%)$ & $9(60 \%)$ & .014 \\
\hline $\begin{array}{l}\text { Overall survival (days) } \\
\text { (median) }\end{array}$ & 309 & 216 & 334 & .11 (log rank) \\
\hline
\end{tabular}

investigated the $P D-1$ promoter methylation in sorted $\mathrm{CD}^{+}$and $\mathrm{CD} 8^{+} \mathrm{T}$ cells. $P D-1$ promoter methylation was examined in both $\mathrm{CD} 8^{+} \mathrm{T}$ cells and $\mathrm{CD} 4^{+} \mathrm{T}$ cells because of their cooperative function in tumor surveillance. Ten of the 22 patients were also included in the analyses of PBMNCs described above.

The 22 patients had received a median number of five courses of 5-aza (range 3-14). A total of 132 PB samples were sorted and analyzed. Nine (41\%) of the patients demonstrated a significant decrease in $P D-1$ promoter methylation in the T cell compartment after 5-aza administration (Figure 3A and 3B). In two of these patients we only observed demethylation in either the $\mathrm{CD}^{+} \mathrm{T}$ cells or the $\mathrm{CD} 8^{+} \mathrm{T}$ cells. In the remaining 13 patients an increase in $P D-1$ methylation or no methylation changes were observed (Figure 4A and 4B). The mean baseline methylation level in $\mathrm{T}$ cells was significantly higher in the group of patients in whom we observed a demethylation of the $P D-1$ promoter, both compared to patients where no demethylation were observed (48.0\% (SD 15.8) vs. $25.7 \%$ (SD 9.4) $(p<.001,95 \%$-CI [13.1;31.5]), and compared to healthy donors ( $48.0 \%$ (SD 15.8) vs. $24.5 \%$ (SD 11.1) $(p<.0001,95 \%$-CI [11.7;35.4])) (Figure 5). A trend towards higher $P D-1$ baseline methylation in the patients' PBMNCs and T cells compared to those of healthy donors was observed (PBMNCs, $p=0.07 ; 95 \%$-CI $[-1.7 ; 38.2]$, $\mathrm{T}$ cells, $p=0.16 ; 95 \%$-CI $[-3.0 ; 17.7])$.

Comparison of the methylation levels in PBMNCs and $\mathrm{T}$ cells from the 10 patients, where data on both cell types were available, reveals a difference in the baseline levels as well as a difference during treatment. In six of the ten patients we observed a good correlation between the relative methylation level in PBMNCs and T cells during treatment, either occurring as demethylation or no demethylation in both cell populations. In one patient we observed a demethylation in PBMNCs and $\mathrm{CD} 4^{+} \mathrm{T}$ cells but not in $\mathrm{CD} 8^{+} \mathrm{T}$ cells, and in three patients demethylation was seen in the compound PBMNC population; however, no demethylation was observed in the T cells at the corresponding time points (Supplementary Figure 1). Accordingly, changes in $P D-1$ methylation in PBMNCs do not always reflect the changes in the T cell compartment, emphasizing the importance of analyzing sorted cells. 

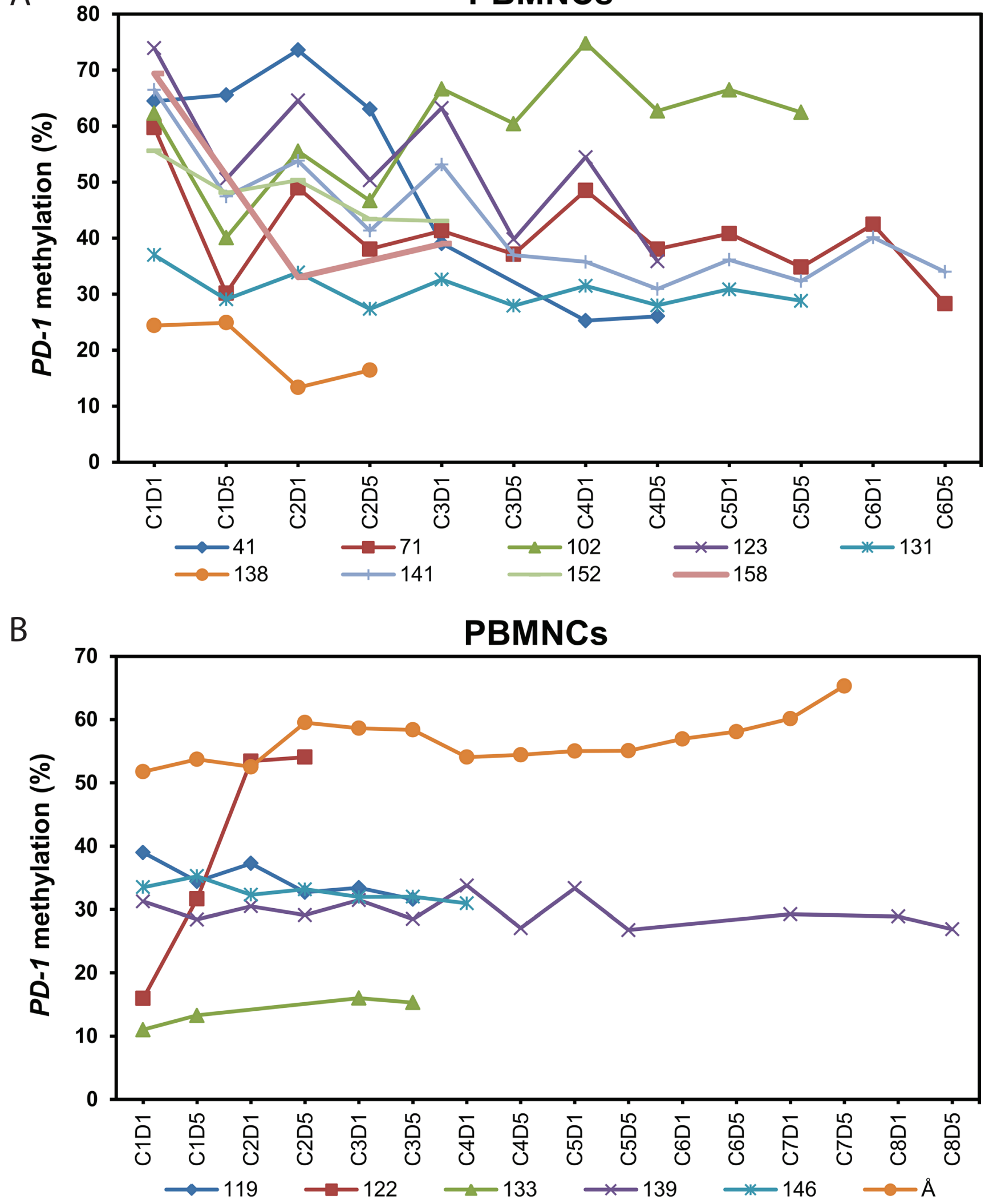

Figure 2: Dynamics of $P D-1$ promoter methylation in peripheral blood mononuclear cells of 15 patients during treatment with 5-azacytidine. (A) $P D-1$ promoter methylation in the 9 patients in whom we observed a classifiable demethylation. (B) $P D-1$ promoter methylation in the 6 patients in whom we did not observe a classifiable demethylation. $\mathrm{C}=$ course of 5 -aza treatment. $\mathrm{D}=$ day in treatment course. $\mathrm{PBMNC}=$ peripheral blood mononuclear cells. 


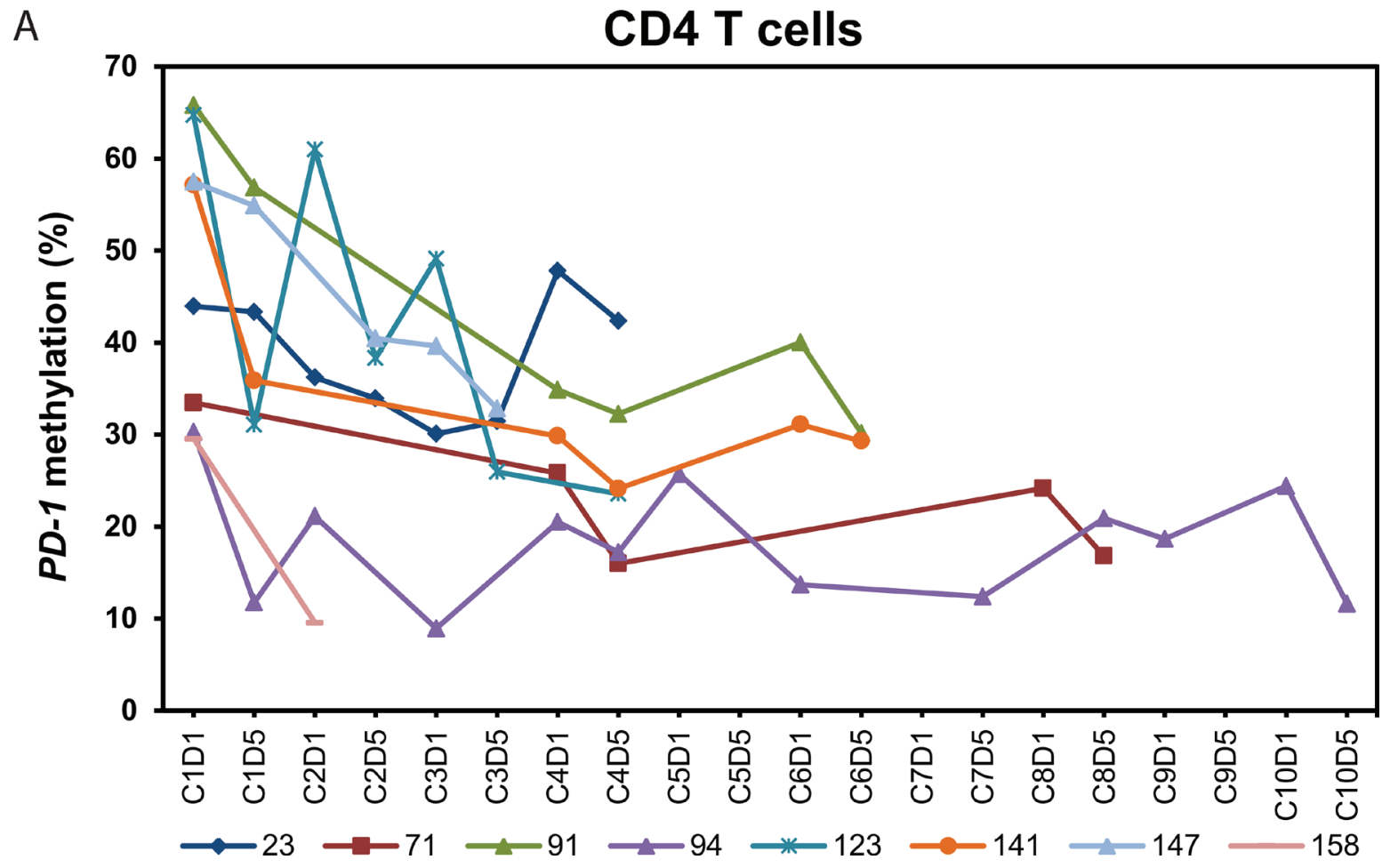

B

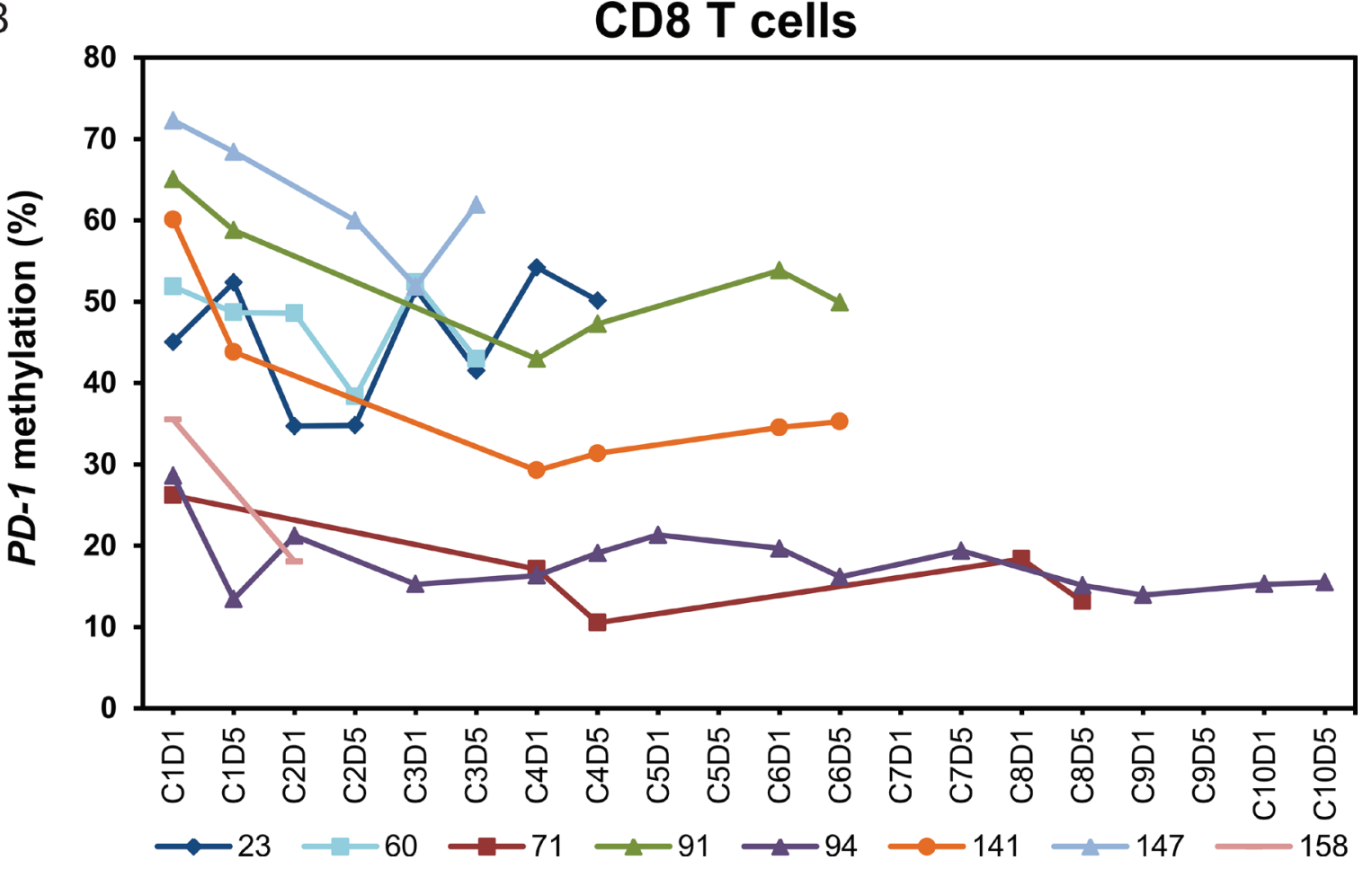

Figure 3: Dynamics of $P D-1$ promoter methylation in peripheral blood $\mathrm{CD4}^{+}$and $\mathrm{CD8}^{+} \mathrm{T}$ cells from the patients with $P D-1$ promoter demethylation during treatment with 5-azacytidine. (A) $P D-1$ promoter methylation in $\mathrm{CD}^{+} \mathrm{T}$ cells of eight patients. (B) $P D-1$ promoter methylation in $\mathrm{CD} 8^{+} \mathrm{T}$ cells of eight patients. In patient no. 123 we only observed demethylation in the $\mathrm{CD}^{+}$ $\mathrm{T}$ cells $\left(\mathrm{CD} 8^{+} \mathrm{T}\right.$ cells from patient no. 123 are included in Figure 4B) and in patient no. 60 we only observed demethylation in the $\mathrm{CD} 8^{+} \mathrm{T}$ cells $\left(\mathrm{CD}^{+} \mathrm{T}\right.$ cells from patient no. 60 are included in Figure 4A). $\mathrm{C}=$ course of 5-aza treatment. $\mathrm{D}=$ day in treatment course. 

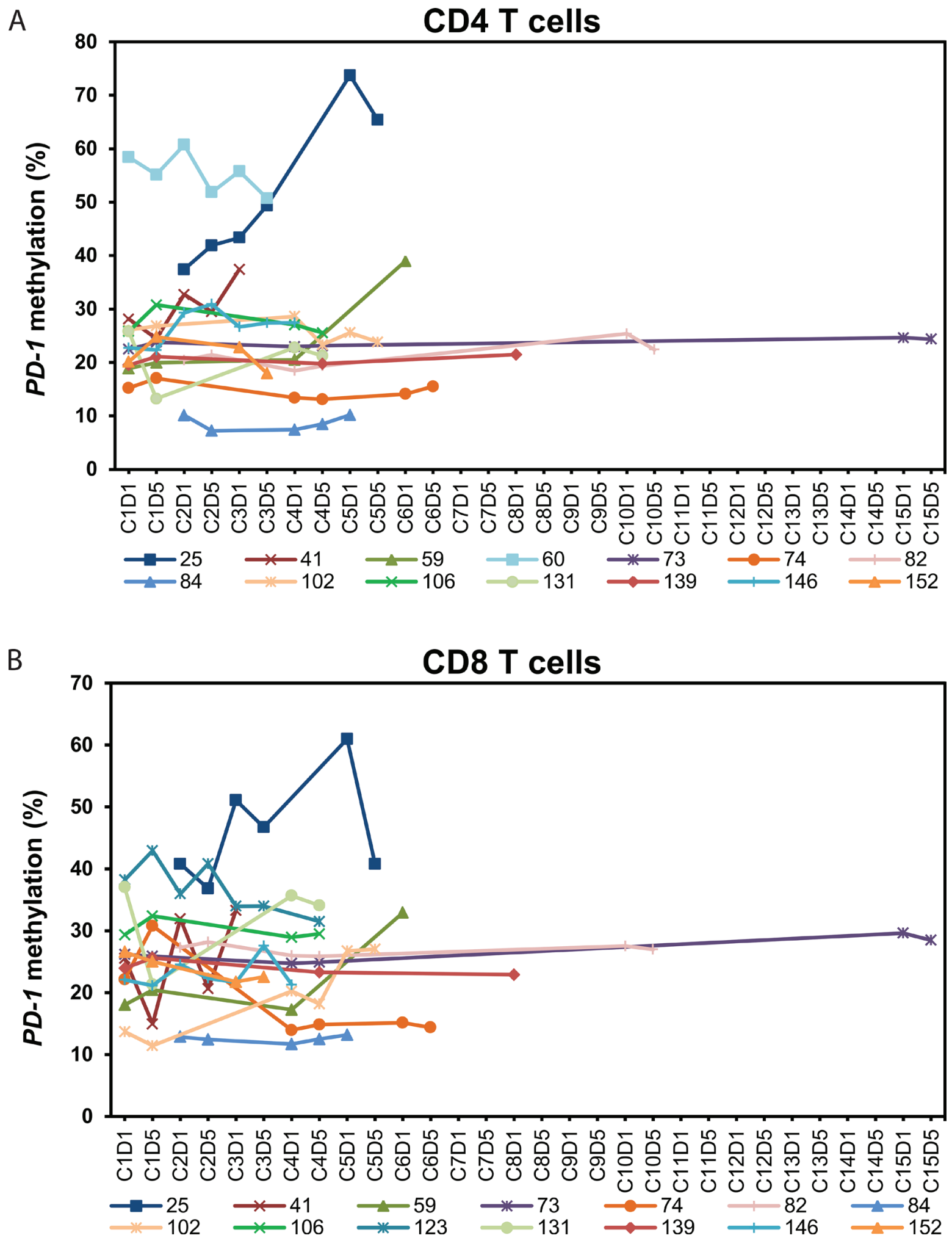

Figure 4: Dynamics of $P D-1$ promoter methylation in peripheral blood $\mathrm{CD4}^{+}$and $\mathrm{CD8}^{+} \mathrm{T}$ cells from patients without $P D-1$ promoter demethylation during treatment with 5-azacytidine. (A) $P D-1$ promoter methylation in $\mathrm{CD}^{+} \mathrm{T}$ cells of 14 patients. (B) $P D-1$ promoter methylation in $\mathrm{CD}^{+} \mathrm{T}$ cells of 14 patients. In patient no. 123 we observed demethylation in the $\mathrm{CD} 4^{+} \mathrm{T}$ cells $\left(\mathrm{CD} 4^{+} \mathrm{T}\right.$ cells from patient no. 123 are included in Figure $\left.3 \mathrm{~A}\right)$ and in patient no. 60 we observed demethylation in the $\mathrm{CD} 8^{+} \mathrm{T}$ cells $\left(\mathrm{CD} 8^{+} \mathrm{T}\right.$ cells from patient no. 60 are included in Figure $3 \mathrm{~A}$ ). $\mathrm{C}=$ course of 5 -aza treatment. $\mathrm{D}=$ day in treatment course. 


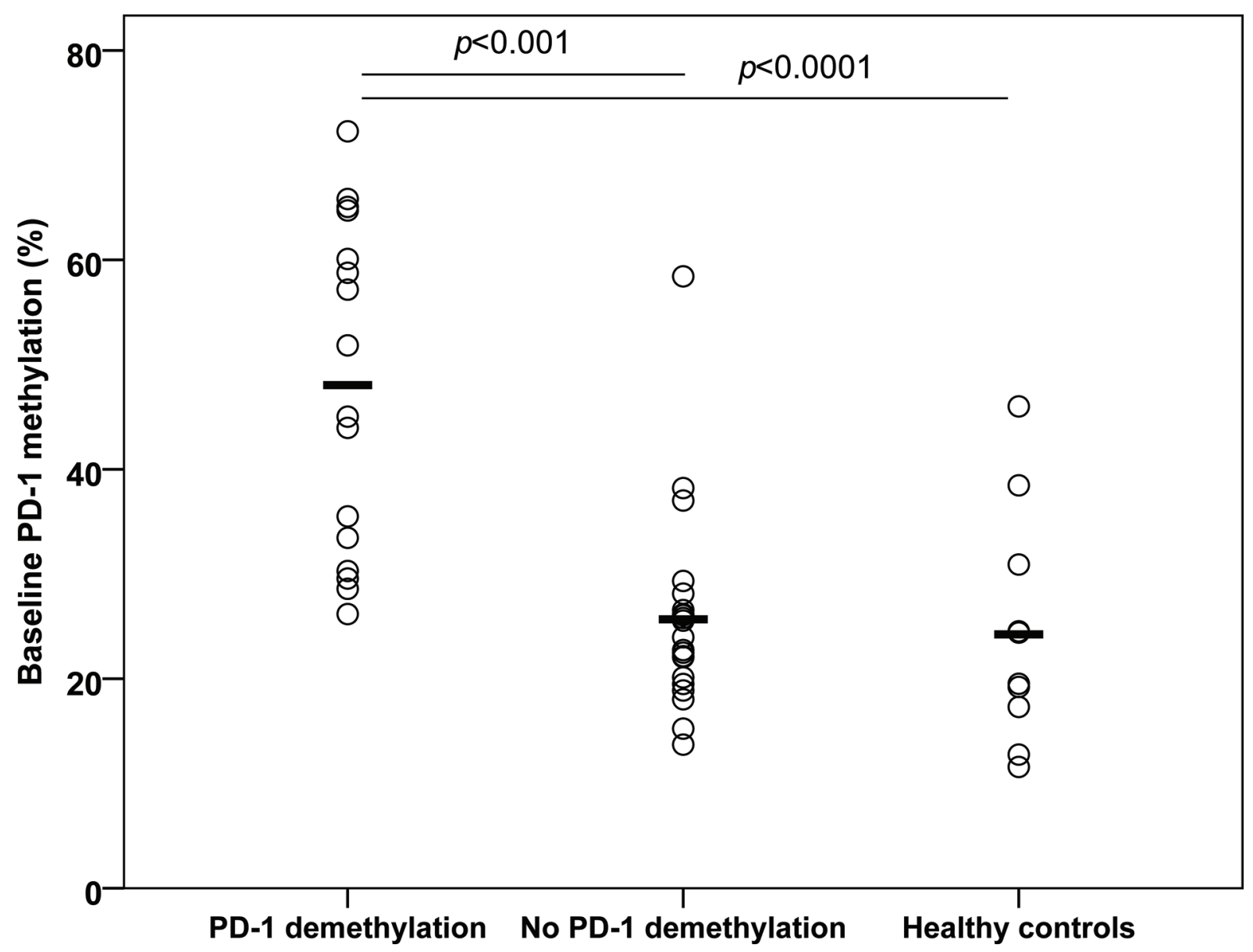

Figure 5: Baseline $P D-1$ promoter methylation in peripheral blood $\mathrm{CD}^{+}$and $\mathrm{CD8}^{+} \mathrm{T}$ cells from 5 -azacytidine treated patients and five healthy donors. The patients are grouped according to whether the $P D-1$ promoter demethylates or not during treatment. The values for $\mathrm{CD}^{+}$and $\mathrm{CD}^{-} \mathrm{T}$ cells are pooled.

Altogether, the methylation analyses revealed demethylation of the $P D-1$ promoter during 5-aza treatment in 12 of $27(44 \%)$ patients.

\section{PD-1 expression in $\mathrm{CD4}^{+}$and $\mathrm{CD8}^{+} \mathrm{T}$ cells from 5-aza treated patients}

To investigate whether demethylation of the $P D-1$ promoter during 5-aza treatment leads to an increased expression of $P D-1$, we examined the expression of $P D-1$ mRNA in the same cells before and during 5-aza treatment. The gene expression was examined in ten patients; $P D-1$ promoter demethylation in $\mathrm{CD}^{+}$and/ or $\mathrm{CD}^{+} \mathrm{T}$ cells correlated with an increase in $P D-1$ expression. No $P D-1$ up-regulation was observed in the patients without demethylation of the $P D-1$ promoter.

Moreover, to support the correlation between increased $P D-1$ mRNA and cell surface protein expression, we performed multiparameter flow cytometry on PBMNCs from four patients by measuring the PD-1 expression (median fluorescence intensity, MFI) on $\mathrm{CD}^{+} \mathrm{T}$ cells expressing the activating marker $\mathrm{CD} 45 \mathrm{RO}$
(Figure 6). The two patients showing a $P D-1$ promoter demethylation and increase in $P D-1$ mRNA expression following 5-aza treatment markedly increased the PD-1 protein surface expression level too, compared to the other two patients with no demethylation of the $P D-1$ promoter.

\section{Correlation between methylation and expression in $\mathrm{CD}^{+}$and $\mathrm{CD8}^{+} \mathrm{T}$ cells from 5 -aza treated patients}

Next we compared the $P D-1$ gene expression to the $P D-1$ promoter methylation levels in T cells from the ten patients where corresponding values of the parameters were available. We found a statistically significant inverse correlation between the $P D-1$ promoter methylation and expression level $(p<0.0001)$ (Figure 7).

\section{Correlation between clinical response and PD-1 promoter methylation}

Due to PD-1's inhibiting role on anti-tumor immune responses, we wanted to investigate whether demethylation 


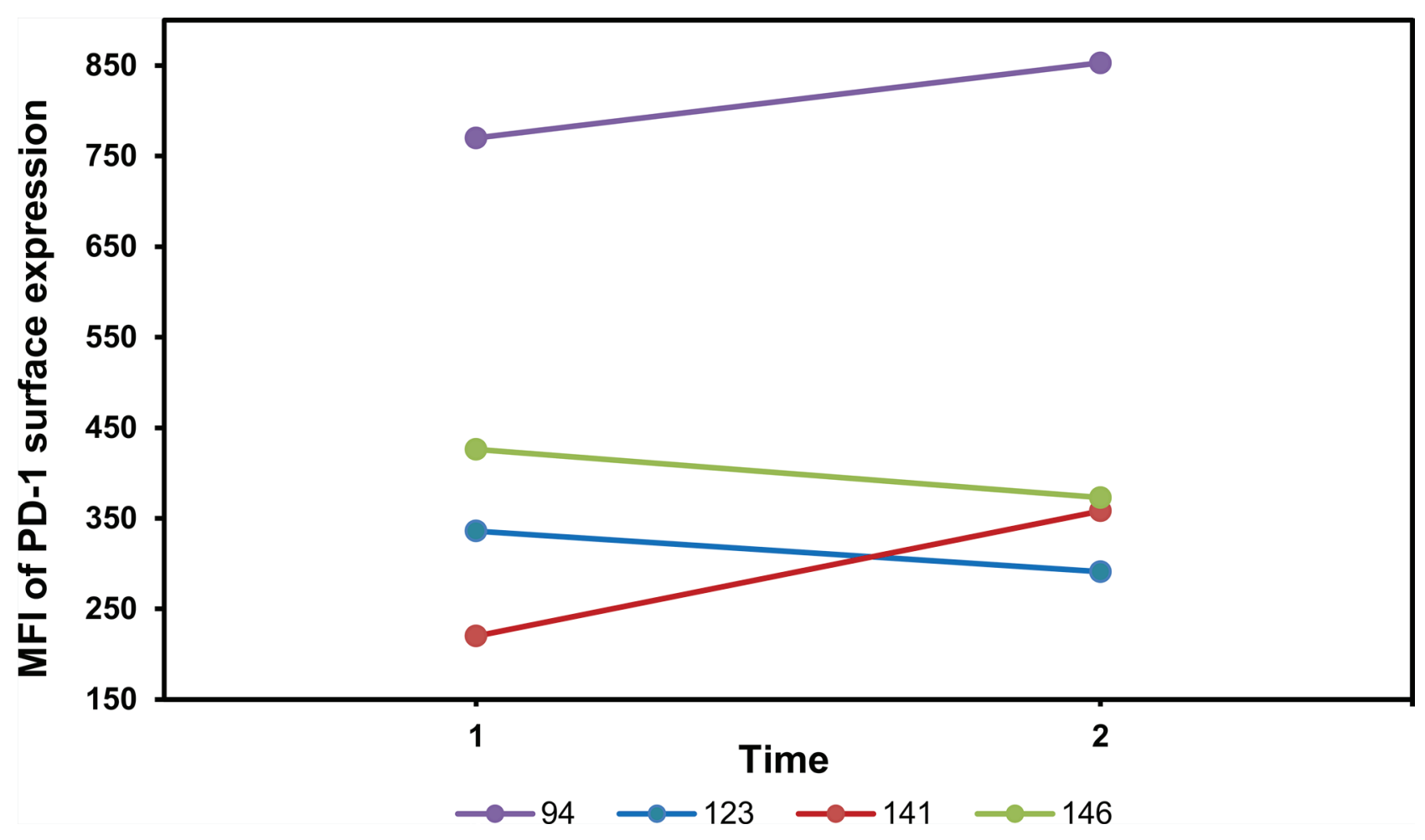

Figure 6: PD-1 protein surface expression on $\mathbf{C D 8}^{+} \mathbf{T}$ cells from 5-aza treated patients. $P D-1$ protein surface expression, as expressed by the median fluorescence intensity (MFI), on $\mathrm{CD}^{+} / \mathrm{CD} 45 \mathrm{RO}^{+} \mathrm{T}$ cells from PBMNCs of four patients at baseline before 5 -aza treatment (1) and following the first treatment cycle (2) (the first available sample for every patient after the first treatment cycle. Patient no. 94, 123, 141 and 146: C4D5, C3D1, C2D1 and C3D1, respectively (C = course of 5-aza treatment. $\mathrm{D}=$ day in treatment course)). In patient no. 94 and 141 an increase in PD-1 protein expression is observed (MFI: 770 to 853 (MFIR: 1.11), and MFI: 220 to 358 (MFIR: 1.63), respectively), whereas in patient no. 123 and 146 no increase is observed (MFI: 336 to 291 (MFIR: 0.89), and MFI: 426 to 373 (MFIR: 0.88), respectively). Correspondingly, we observed a significant demethylation of the $P D-1$ promoter during treatment in $\mathrm{CD} 8^{+} \mathrm{T}$ cells in patient no. 94 and 141 (Figure 3B) and no demethylation in patient no. 123 and 146 (Figure 4B). Moreover, we saw a higher baseline MFI of PD-1 in patient 94 compared to patient 141, which is in line with the variation in baseline methylation level.

of the $P D-1$ promoter in T cells and PBMNCs during 5-aza treatment is correlated to the clinical response. A significant difference in overall response rate (ORR) was observed when comparing patients with and without $P D-1$ promoter demethylation (Table 1). In the group of patients with $P D$ 1 promoter demethylation, only one of $12(8 \%)$ patients showed an overall response to 5 -aza. Of the 15 patients with no demethylation an overall response was observed in 9 patients (60\%). The ORR was significantly higher in the group of patients without $P D-1$ promoter demethylation $(p=0.014)$. Furthermore, a trend towards longer OS was seen in the patients without $P D-1$ promoter demethylation $(p=0.11)$ (Supplementary Figure 2). Non-responding patients had a significantly higher baseline PD-1 promoter methylation compared to healthy controls $(38.2 \%$ vs. $24.5 \% ; p=0.023,95 \%$-CI $[2.0 ; 25.4])$ and a trend towards a higher baseline PD-1 promoter methylation compared to responding patients $(28.5 \%$ vs. $38.2 \% ; p=0.096,95 \%$-CI [-21.1;1.8]) (Figure 8). Taken together, these data indicate that demethylation of the $P D-1$ promoter in T cells during 5 -aza treatment might be associated with a poorer clinical response to 5-aza.

\section{DISCUSSION}

Treatment with HMAs has become the standard of care in higher-risk MDS patients who are not eligible for allogeneic hematopoietic stem cell transplantation, and is also approved for CMML and AML patients with 20-30\% blasts. Even though the effects of single agent therapy with HMAs are encouraging, remissions are not long lasting, and novel treatment modalities are urgently needed in MDS. Within recent years immune modulating agents have shown promise as novel anti-cancer agents in both experimental and clinical studies in solid tumors [24, 25].

It was recently shown that up-regulation of the immune inhibitory receptor PD-1 on $\mathrm{T}$ cells during infections is coupled to demethylation of $\mathrm{CpG}$ sites in the $P D-1$ promoter [18]. During the development of T cells from naïve to activated and memory $\mathrm{T}$ cells, the $P D-1$ promoter changes from methylated to unmethylated and back to methylated again. Under normal circumstances, demethylation of the $P D-1$ promoter appears to be mediated by ligation of the T cell receptor (TCR) [26]. Youngblood et al. showed that 5 -aza was able to sustain 


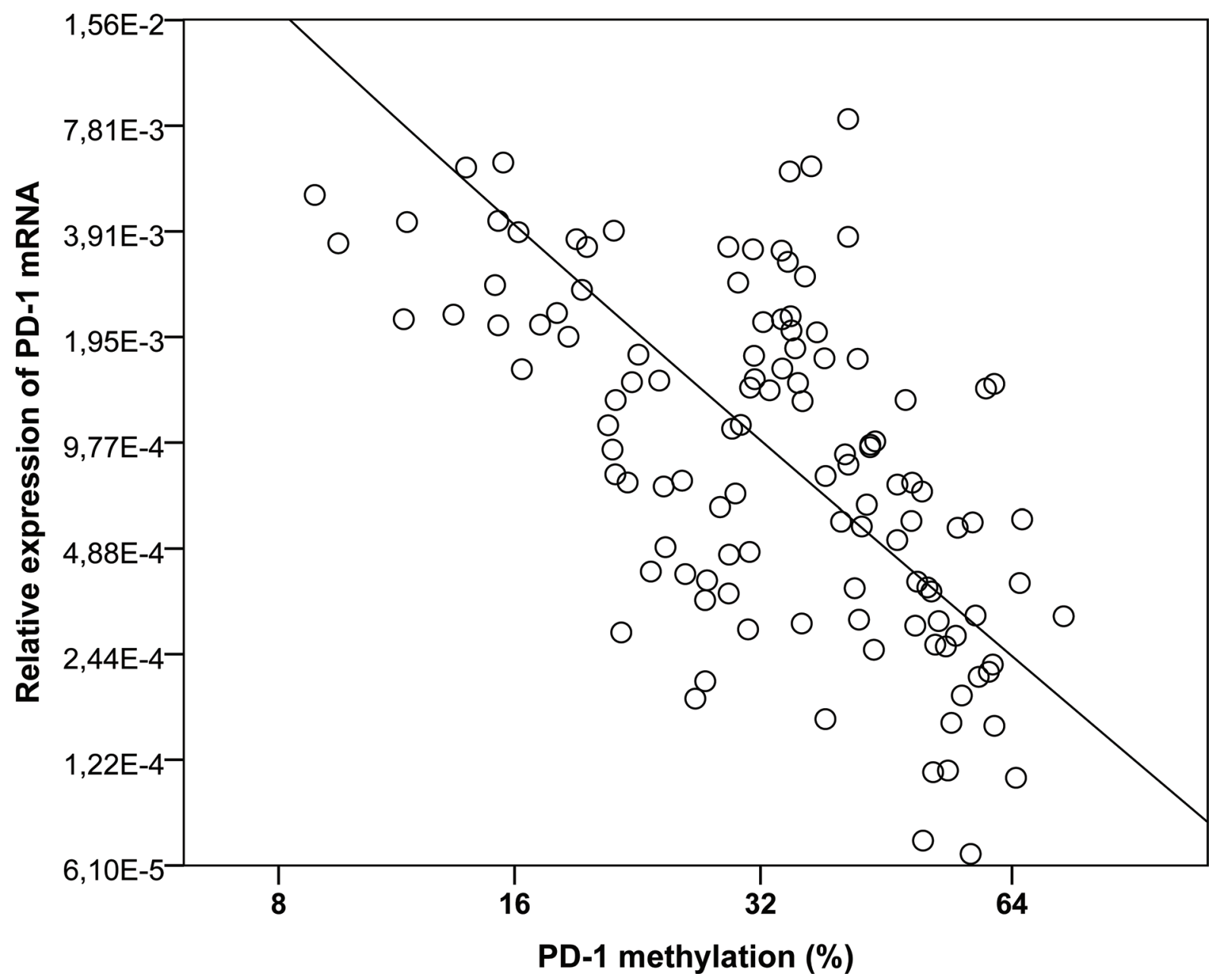

Figure 7: Correlation between $P D-1$ promoter methylation and $P D-1$ gene expression in peripheral blood $\mathrm{CD}^{+}$ and $\mathrm{CD8}^{+} \mathbf{T}$ cells from 5-azacytidine treated patients. Ten patients and their corresponding values of methylation and relative expression before and during 5-aza treatment (altogether 117 pairs of observations). Methylation level is plotted as co-variate and the relative expression as outcome on a $\log \log$ scale with the base 2 . The linear regression reveals a statistically significant inverse relationship between the two log-transformed variables $(p<.0001)$ with the regression coefficient -2.0936 (SE 0.2521 ).

a high expression of $P D-1$ mRNA and protein in vitro, indicating that DNA methylation causes PD-1 repression. Interestingly, during chronic infections, the $P D-1$ promoter remains unmethylated with continuous PD-1 overexpression in the chronically activated T cells, leading to exhausted and dysfunctional T cells [27]. Furthermore, it appears that persistent antigen expression by malignant tumors, like chronic infections, can promote the expression of inhibitory surface molecules on T cells, which can cause functional $\mathrm{T}$ cell exhaustion [28]. Our study suggests that 5-aza treatment may facilitate the exhaustion of tumor-specific $\mathrm{T}$ cells in patients and provides a possible explanation for the development of 5-aza resistance.

One recent study by Yang et al. has examined the effect of HMAs on $P D-1$ expression and methylation during the first treatment cycle. In a heterogeneous cohort of 61 patients (MDS, CMML and AML) treated with HMAs (the majority (87\%) in combination with other agents) up-regulation ( $\geq 2$-fold) of $P D$ - 1 gene expression in PBMNCs was observed during the first cycle of therapy in $58 \%$ of the patients. In a subgroup of 18 patients $P D-1$ promoter methylation in PBMNCs was investigated, and the baseline methylation levels were higher in resistant patients as compared to responding patients - a trend also observed in the current study of sorted T cells. Moreover, Yang et al. observed that the methylation level during the first treatment course was more dynamic in resistant patients as compared to responding patients [22].

Here, we have demonstrated that in vivo treatment with 5-aza has direct impact on the expression of $P D-1$. Treatment with 5-aza was accompanied by a loss of DNA methylation in the $P D-1$ promoter in $44 \%$ (12 of 27) of the patients and the methylation level of the promoter was inversely correlated with $P D-1$ gene expression in T cells. Flow cytometry analyses of the PD-1 protein expression on $\mathrm{CD} 8^{+} \mathrm{T}$ cells supported the correlation between the 


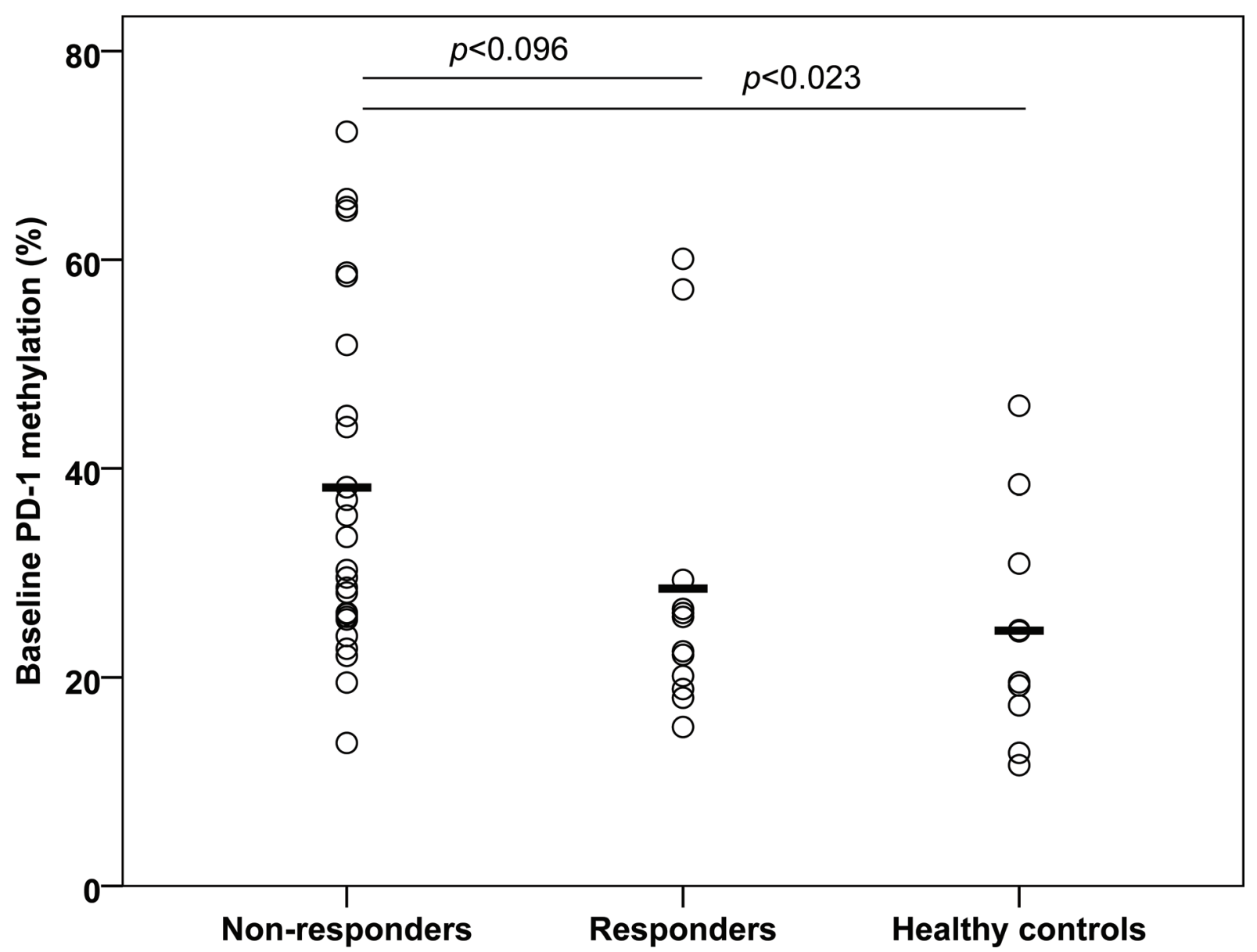

Figure 8: Baseline $P D-1$ promoter methylation in peripheral blood $\mathrm{CD}^{+}$and $\mathrm{CD}^{+} \mathrm{T}$ cells from 5-azacytidine treated patients and five healthy donors. The patients are grouped according to whether they responded or not responded to the treatment. The values for $\mathrm{CD}^{+}$and $\mathrm{CD} 8-\mathrm{T}$ cells are pooled.

increase in $P D-1$ mRNA and the expression of PD-1 cell surface protein. Our combined analyses of both PBMNCs and sorted $\mathrm{T}$ cells in ten patients revealed that the $P D-1$ promoter methylation changes observed in the PBMNCs do not always reflect the methylation changes in the $\mathrm{T}$ cell population. This is probably due to changes in the composition of the PBMNCs rather than changes in the $P D-1$ promoter methylation, emphasizing the importance of sorting out the relevant cells in such studies.

Interestingly, we found a significantly higher ORR and a trend towards a better OS in patients without demethylation of the $P D-1$ promoter during 5-aza treatment. The baseline $P D-1$ methylation level was significantly higher in patients where a demethylation was observed, both compared to normal controls and to patients where no demethylation was observed. Furthermore, a significantly higher baseline $P D-1$ methylation level was observed in non-responding patients compared to healthy controls. In addition, we demonstrate that a clinical relevant $P D-1$ demethylation is not limited to the first treatment cycle but occurs throughout the treatment course. Accordingly, we believe that our study, on isolated
$\mathrm{T}$ cell populations and with longer follow-up time, is an important extension to the initial findings of Yang et al.

A few studies indicate that PD-L1 and PD-L2 is overexpressed in higher-risk MDS $[22,23]$ and that PDL1 may also be induced by 5-aza treatment [29]. It has furthermore been shown that expression of PD-L1 is an independent negative prognostic factor in different malignancies $[13,15]$. This relates to the fact that the PD-1/ PD-L1 pathway is a central mediator of T cell exhaustion (as well as inducer of T cell apoptosis [17]). Thus, expression of the PD-1 ligands on tumor cells appears to be an important way of evading the specific tumor immune response. Recent clinical trials with blockade of the PD-1 pathway have shown significant clinical responses in solid tumors [30, 31]. The flow cytometry data presented in this study together with previous in vitro and murine studies $[18,23,32]$ indicate a positive correlation between $P D-1$ gene expression and surface expression in vivo; thus, we believe that the observed $P D-1$ demethylation and mRNA up-regulation lead to increased PD-1 surface expression on activated T cells.

Interestingly, we show that demethylation of the $P D$-1 promoter during 5-aza treatment correlates with a 
poorer ORR. This suggests that $P D-1$ up-regulation in T cells caused by 5 -aza might be involved in the impaired response/ development of resistance to 5-aza treatment observed in a substantial fraction of patients. Obviously, our findings need validation in a larger and uniformly treated cohort. However, this study provides an important demonstration of 5-aza being able to up-regulate $P D-1$, a key immunoinhibitory receptor, in patients' $\mathrm{T}$ cells in vivo. We believe that the observed effect of 5-aza on PD-1 may accelerate the development of dysfunctional effector $\mathrm{T}$ cells leading to primary or secondary resistance. We therefore suggest that combination therapy with a HMA and a PD-1 pathway inhibitor in the treatment of higher-risk MDS will release this "brake" on the tumor-specific T cells, potentially enhancing their function. A reinforced immune response against the malignant blasts may improve the clinical outcomes in MDS.

\section{MATERIALS AND METHODS}

\section{Patients and treatment}

Peripheral blood (PB) was sampled from 27 patients with $\operatorname{MDS}(n=19), \operatorname{CMML}(n=3)$ and $\operatorname{AML}(n=5)$ and 5 healthy donors. The patient samples were collected at the Department of Hematology, Rigshospitalet, Copenhagen, and Aarhus University Hospital, Aarhus, between 2008 and 2011. The study was approved by the Regional Ethical Committee. All patients had signed informed consent according to the Declaration of Helsinki. All patients were diagnosed according to the World Health Organization (WHO) criteria [33], and the International Prognostic Scoring System (IPSS) [34] was used to stratify the MDS patients into risk-groups. Seven patients were classified as IPSS intermediate-1; they all progressed before the initiation of 5-aza treatment. The patients were treated with $100 \mathrm{mg} / \mathrm{m}^{2}$ s.c. 5-aza (Vidaza, Celgene, NJ) for five consecutive days in each 28-day cycle, according to the Nordic MDS guidelines (http://www.nmds.org/NordicCare-Programme). PB samples were collected from each patient before 5-aza administration on day one and day five in each individual course of 5-aza treatment.

The clinical response to treatment was evaluated in accordance with the revised International Working Group (IWG) response criteria [35]. Overall response was defined as complete remission (CR), partial remission (PR), marrow CR with hematologic improvement (HI) and stable disease (SD) with HI. CR in the bone marrow without HI and SD without HI were defined as no response.

Patient characteristics and response to treatment are summarized in Table 1.

\section{Isolation of mononuclear cells and sorting of $\mathrm{CD4}^{+}$and $\mathrm{CD8}^{+} \mathrm{T}$ cells}

Peripheral blood mononuclear cells (PBMNCs) were isolated from peripheral blood immediately after sampling by using Ficoll-Paque PLUS (GE Healthcare) densitygradient centrifugation and thereafter cryopreserved at $\sim-196^{\circ} \mathrm{C}$ for later use. The frozen PBMNCs were thawed and thereafter immediately separated into $\mathrm{CD} 4^{+}$ and $\mathrm{CD}^{+} \mathrm{T}$ cells using magnetic bead-based separation on a RoboSep device according to the manufacturer's instructions (StemCell Technologies). Separation of cell subsets from the healthy donors was performed on freshly isolated PBMNCs.

\section{Nucleic acid extraction}

Genomic DNA from MNCs was isolated using Gentra Puregene Cell Kit (Qiagen). Genomic DNA and total RNA from separated $\mathrm{CD}^{+}$and $\mathrm{CD}^{+} \mathrm{T}$ cells were extracted using the AllPrep DNA/RNA/miRNA Universal Kit (Qiagen) according to the manufacturer's protocol. The DNA and RNA quantity and quality were controlled on a spectrophotometer (Eppendorf BioPhotometer).

\section{Bisulfite conversion and pyrosequencing}

$250 \mathrm{ng}$ of genomic DNA was bisulfite converted using the EZ DNA Methylation kit (Zymo Research) with a slight modification. Samples were incubated at $42^{\circ} \mathrm{C}$ for 30 minutes instead of $37^{\circ} \mathrm{C}$ for 15 minutes. For the bisulfite reaction the alternative incubation conditions described in the appendix were used. The bisulfite-treated DNA was amplified by performing polymerase chain reaction (PCR) with locus-specific primers for the $P D-1$ gene promoter using PyroMark Gold master mix. Forward primer: 5'-TTTGTGGATGGTTTTATATTATGGTTATAG-3'.

Reverse primer: 5'-biotin-TCACAACCAACCCCTACC-3'. The PCR was performed on the Gene PCR System 9700 (Applied Biosystems). PCR cycling conditions were as follows: One cycle of $95^{\circ} \mathrm{C}$ for $15 \mathrm{~min}$, followed by 45 cycles of $94^{\circ} \mathrm{C}$ for $20 \mathrm{~s}, 60^{\circ} \mathrm{C}$ for $20 \mathrm{~s}$ and $72^{\circ} \mathrm{C}$ for $20 \mathrm{~s}$, and one cycle of $72^{\circ} \mathrm{C}$ for $10 \mathrm{~min}$. Methylation analysis was done by pyrosequencing of the $P D-1$ promoter carried out on a PyroMark Q24 (Qiagen) using the PyroMark Gold Q24 reagents (Qiagen), according to the manufacturer's instructions. Sequencing primer: 5'-ATTATGGTTATAGTTTTAGATTTTT-3'. The design of the pyrosequencing assay was based on a former publication [18]. The assay covers three CpG-sites in the upstream DNA-sequence of the transcriptional start site of the $P D-1$ gene (Supplementary Figure 3) [18]. The $P D-1$ methylation level for a given sample was calculated as a mean of the methylation $\%$ of the three investigated $\mathrm{CpG}$-sites.

\section{Real-time quantitative polymerase chain reaction}

250 ng of total RNA was used for reverse transcription reactions to generate cDNA using SuperScript III Reverse Transcriptase and random hexamer primers 
(Invitrogen). Real-time quantitative PCR (RT-qPCR) of the $P D-1$ cDNA was performed using TaqMan assays (id. Hs01550088_m1, Applied Biosystems) [36]. The amplification was performed on a LightCycler 480 II instrument. The amplification curves were analyzed using Roche LightCycler version 1.5.1.62 software for determination of crossing point $(\mathrm{Cp}$, by the second derivative method). All RT-qPCR assays were carried out in duplicate and then repeated with new cDNA synthesis. Reverse transcriptase negative cDNA synthesis reactions were performed for at least one sample per plate. Gene expression was normalized to endogenous $G A P D H$ (TaqMan assay, id. Hs99999905_m1) expression and relative gene expression was calculated by using the

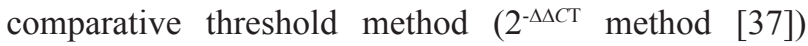
normalized to cDNA from $\mathrm{T}$ cells from the same patient at baseline of 5-aza treatment.

\section{Flow cytometry}

Cryopreserved PBMNCs were thawed, incubated with an Fc receptor blocking reagent (ChromPure Mouse IgG, Jackson ImmunoResearch Suffolk, UK) to inhibit non-specific binding before incubated with the following, pre-titrated antibodies (all from BD Biosciences, San Jose, CA): anti-CD3 V450, anti-CD45RO FITC, anti-PD-1 (CD279) PE, and anti-CD8 AF700. Flow cytometry was acquired by a LSRFortessa (BD Biosciences, San Diego, CA) and data analyzed using FlowJo version 10.2 (Tree Star Inc., Ashland, OR). Compensation was performed using BD CompBeads (BD Biosciences). Applying gating strategies based on unstained controls and for PD-1 the fluorescence minus one (FMO), the expression of PD-1 was measured on $\mathrm{CD}^{+} / \mathrm{CD} 45 \mathrm{RO}^{+} / \mathrm{CD}^{+}$singlets and given by the median fluorescense intensity (MFI) (Supplementary Figure 4).

\section{Statistical analysis}

Differences in clinical characteristics for patients with or without demethylation of the $P D-1$ promoter during 5-aza treatment were compared using the Pearson chi-squared test, or Fischer's exact test if appropriate, for categorical variables and the Wilcoxon rank sum test for continuous variables. Overall survival was analyzed by the Kaplan-Meier method and compared using the log-rank test. Survival was measured from the onset of 5-aza therapy. Patients who were alive were censored at the date of last follow-up. Patients who underwent BM transplantation were censored at the day of transplantation. Statistically significant changes in gene promoter methylation were assessed by a linear mixed model (a three-level model) because of the correlation of within-patient measurements. Regression analysis of the association of gene promoter methylation and gene expression was calculated using mixed models due to the occurrence of repeated measurements. The mixed model analyses were performed using the SAS Enterprise Guide 4.3 (SAS Institute, NC). All other statistical analyses were performed using SPSS version 22.0.0 (IBM, NY). Significance level was 5\% and two-sided for all analyses.

\section{ACKNOWLEDGMENTS}

This study has been supported by grants from Rigshospitalets Research Foundation (A.D.Ø.), the Novo Nordisk Foundation (K.G., M.B.T.), and the Danish Cancer Society (K.G.). The authors would like to thank Anja Pedersen for skillful technical assistance, and Assoc. Prof. Julie Lyng Forman for helpful statistical discussion.

\section{DISCLOSURE OF CONFLICTS OF INTEREST}

The authors declare no competing financial interests.

\section{REFERENCES}

1. Tefferi A, Vardiman JW. Myelodysplastic syndromes. N. Engl. J. Med. 2009; 361:1872-85.

2. Fenaux P, Mufti GJ, Hellstrom-Lindberg E, Santini V, Finelli C, Giagounidis A, Schoch R, Gattermann N, Sanz G, List A, Gore SD, Seymour JF, Bennett JM, et al. Efficacy of azacitidine compared with that of conventional care regimens in the treatment of higher-risk myelodysplastic syndromes: a randomised, open-label, phase III study. Lancet Oncol. 2009; 10:223-32.

3. Kantarjian H, Issa J-PJ, Rosenfeld CS, Bennett JM, Albitar M, DiPersio J, Klimek V, Slack J, de Castro C, Ravandi F, Helmer R, Shen L, Nimer SD, et al. Decitabine improves patient outcomes in myelodysplastic syndromes: results of a phase III randomized study. Cancer. 2006; 106:1794-803.

4. Lübbert M, Suciu S, Baila L, Rüter BH, Platzbecker U, Giagounidis A, Selleslag D, Labar B, Germing U, Salih HR, Beeldens F, Muus P, Pflüger K-H, et al. Low-dose decitabine versus best supportive care in elderly patients with intermediate- or high-risk myelodysplastic syndrome (MDS) ineligible for intensive chemotherapy: final results of the randomized phase III study of the European Organisation for Rese. J. Clin. Oncol. 2011; 29:1987-96.

5. Fenaux P, Mufti GJ, Hellström-Lindberg E, Santini V, Gattermann N, Germing U, Sanz G, List AF, Gore S, Seymour JF, Dombret H, Backstrom J, Zimmerman L, et al. Azacitidine prolongs overall survival compared with conventional care regimens in elderly patients with low bone marrow blast count acute myeloid leukemia. J. Clin. Oncol. $2010 ; 28: 562-9$.

6. Kantarjian HM, Thomas XG, Dmoszynska A, Wierzbowska A, Mazur G, Mayer J, Gau J-P, Chou W-C, Buckstein R, Cermak J, Kuo C-Y, Oriol A, Ravandi F, et al. Multicenter, randomized, open-label, phase III trial of decitabine versus patient choice, with physician advice, of 
either supportive care or low-dose cytarabine for the treatment of older patients with newly diagnosed acute myeloid leukemia. J. Clin. Oncol. 2012; 30:2670-7.

7. Prébet $\mathrm{T}$, Gore SD, Esterni $\mathrm{B}$, Gardin $\mathrm{C}$, Itzykson R, Thepot S, Dreyfus F, Rauzy OB, Recher C, Adès L, Quesnel B, Beach CL, Fenaux P, et al. Outcome of highrisk myelodysplastic syndrome after azacitidine treatment failure. J. Clin. Oncol. 2011; 29:3322-7.

8. Gore SD, Baylin S, Sugar E, Carraway H, Miller CB, Carducci M, Grever M, Galm O, Dauses T, Karp JE, Rudek M a, Zhao M, Smith BD, et al. Combined DNA methyltransferase and histone deacetylase inhibition in the treatment of myeloid neoplasms. Cancer Res. 2006; 66:6361-9.

9. Qiu X, Hother C, Ralfkiær UM, Søgaard A, Lu Q, Workman CT, Liang G, Jones P a, Grønbæk K. Equitoxic doses of 5-azacytidine and 5-aza-2'deoxycytidine induce diverse immediate and overlapping heritable changes in the transcriptome. PLoS One. 2010; 5:pii: e12994.

10. Almstedt M, Blagitko-Dorfs N, Duque-Afonso J, Karbach J, Pfeifer D, Jäger E, Lübbert M. The DNA demethylating agent 5-aza-2'-deoxycytidine induces expression of NY-ESO-1 and other cancer/testis antigens in myeloid leukemia cells. Leuk. Res. 2010; 34:899-905.

11. Karpf AR. A potential role for epigenetic modulatory drugs in the enhancement of cancer/germ-line antigen vaccine efficacy. Epigenetics. 2007; 1:116-20.

12. Goodyear O, Agathanggelou A, Novitzky-Basso I, Siddique S, McSkeane T, Ryan G, Vyas P, Cavenagh J, Stankovic T, Moss P, Craddock C. Induction of a CD8+ T-cell response to the MAGE cancer testis antigen by combined treatment with azacitidine and sodium valproate in patients with acute myeloid leukemia and myelodysplasia. Blood. 2010; 116:1908-18.

13. Dougan M, Dranoff G. Immune therapy for cancer. Annu. Rev. Immunol. 2009; 27:83-117.

14. Keir ME, Butte MJ, Freeman GJ, Sharpe AH. PD-1 and its ligands in tolerance and immunity. Annu. Rev. Immunol. 2008; 26:677-704.

15. Sznol M, Chen L. Antagonist antibodies to PD-1 and B7-H1 (PD-L1) in the treatment of advanced human cancer. Clin. Cancer Res. 2013; 19:1021-34.

16. Okazaki T, Honjo T. PD-1 and PD-1 ligands: from discovery to clinical application. Int. Immunol. 2007; 19:813-24.

17. Dong H, Strome SE, Salomao DR, Tamura H, Hirano F, Flies DB, Roche PC, Lu J, Zhu G, Tamada K, Lennon V a, Celis E, Chen L. Tumor-associated B7-H1 promotes T-cell apoptosis: a potential mechanism of immune evasion. Nat. Med. 2002; 8:793-800.

18. Youngblood B, Oestreich KJ, Ha S-J, Duraiswamy J, Akondy RS, West EE, Wei Z, Lu P, Austin JW, Riley JL, Boss JM, Ahmed R. Chronic virus infection enforces demethylation of the locus that encodes PD-1 in antigenspecific CD8(+) T cells. Immunity. 2011; 35:400-12.
19. Pardoll DM. The blockade of immune checkpoints in cancer immunotherapy. Nat. Rev. Cancer. 2012; 12:252-64.

20. Zou W, Chen L. Inhibitory B7-family molecules in the tumour microenvironment. Nat. Rev. Immunol. 2008; 8:467-77.

21. Taube JM, Klein A, Brahmer JR, Xu H, Pan X, Kim JH, Chen L, Pardoll DM, Topalian SL, Anders R a. Association of PD-1, PD-1 ligands, and other features of the tumor immune microenvironment with response to anti-PD-1 therapy. Clin. Cancer Res. 2014; 20:5064-74.

22. Kondo A, Yamashita T, Tamura H, Zhao W, Tsuji T, Shimizu M, Shinya E, Takahashi H, Tamada K, Chen L, Dan K, Ogata K. Interferon-gamma and tumor necrosis factor-alpha induce an immunoinhibitory molecule, B7-H1, via nuclear factor-kappaB activation in blasts in myelodysplastic syndromes. Blood. 2010; 116:1124-31.

23. Yang H, Bueso-Ramos C, Dinardo C, Estecio MR, Davanlou M, Geng Q-R, Fang Z, Nguyen M, Pierce S, Wei Y, Parmar S, Cortes J, Kantarjian H, et al. Expression of PD-L1, PD-L2, PD-1 and CTLA4 in myelodysplastic syndromes is enhanced by treatment with hypomethylating agents. Leukemia. 2013; 1-32.

24. Brahmer JR, Tykodi SS, Chow LQM, Hwu W-J, Topalian SL, Hwu P, Drake CG, Camacho LH, Kauh J, Odunsi K, Pitot HC, Hamid O, Bhatia S, et al. Safety and activity of anti-PD-L1 antibody in patients with advanced cancer. N. Engl. J. Med. 2012; 366:2455-65.

25. Hamid O, Robert C, Daud A, Hodi FS, Hwu W-J, Kefford R, Wolchok JD, Hersey P, Joseph RW, Weber JS, Dronca R, Gangadhar TC, Patnaik A, et al. Safety and tumor responses with lambrolizumab (anti-PD-1) in melanoma. N. Engl. J. Med. 2013; 369:134-44.

26. Youngblood B, Noto A, Porichis F, Akondy RS, Ndhlovu ZM, Austin JW, Bordi R, Procopio F a, Miura T, Allen TM, Sidney J, Sette A, Walker BD, et al. Cutting edge: Prolonged exposure to HIV reinforces a poised epigenetic program for PD-1 expression in virus-specific CD8 T cells. J. Immunol. 2013; 191:540-4.

27. Perez-Gracia JL, Labiano S, Rodriguez-Ruiz ME, Sanmamed MF, Melero I. Orchestrating immune checkpoint blockade for cancer immunotherapy in combinations. Curr. Opin. Immunol. 2014; 27:89-97.

28. Crespo J, Sun H, Welling TH, Tian Z, Zou W. T cell anergy, exhaustion, senescence, and stemness in the tumor microenvironment. Curr. Opin. Immunol. 2013; 25:214-21.

29. Wrangle J, Wang W, Koch A, Easwaran H, Mohammad HP, Vendetti F, Vancriekinge W, Demeyer T, Du Z, Parsana P, Rodgers K, Yen R-W, Zahnow CA, et al. Alterations of immune response of Non-Small Cell Lung Cancer with Azacytidine. Oncotarget. 2013; 4:2067-79.

30. Topalian SL, Hodi FS, Brahmer JR, Gettinger SN, Smith DC, McDermott DF, Powderly JD, Carvajal RD, Sosman JA, Atkins MB, Leming PD, Spigel DR, Antonia SJ, et al. Safety, activity, and immune correlates of anti-PD-1 antibody in cancer. N. Engl. J. Med. 2012; 366:2443-54. 
31. Brahmer JR, Tykodi SS, Chow LQM, Hwu W-J, Topalian SL, Hwu P, Drake CG, Camacho LH, Kauh J, Odunsi K, Pitot HC, Hamid O, Bhatia S, et al. Safety and activity of anti-PD-L1 antibody in patients with advanced cancer. N. Engl. J. Med. 2012; 366:2455-65.

32. Barber DL, Wherry EJ, Masopust D, Zhu B, Allison JP, Sharpe AH, Freeman GJ, Ahmed R. Restoring function in exhausted CD8 T cells during chronic viral infection. Nature. 2006; 439:682-7.

33. Vardiman JW, Thiele J, Arber D a, Brunning RD, Borowitz MJ, Porwit A, Harris NL, Le Beau MM, Hellström-Lindberg E, Tefferi A, Bloomfield CD. The 2008 revision of the World Health Organization (WHO) classification of myeloid neoplasms and acute leukemia: rationale and important changes. Blood. 2009; 114:937-51.

34. Greenberg P, Cox C, LeBeau MM, Fenaux P, Morel P, Sanz G, Sanz M, Vallespi T, Hamblin T, Oscier D,
Ohyashiki K, Toyama K, Aul C, et al. International scoring system for evaluating prognosis in myelodysplastic syndromes. Blood. 1997; 89:2079-88.

35. Cheson BD, Greenberg PL, Bennett JM, Lowenberg B, Wijermans PW, Nimer SD, Pinto A, Beran $M$, de Witte TM, Stone RM, Mittelman M, Sanz GF, Gore SD, et al. Clinical application and proposal for modification of the International Working Group (IWG) response criteria in myelodysplasia. Blood. 2006; 108:419-25.

36. Arya M, Shergill IS, Williamson M, Gommersall L, Arya N, Patel HRH. Basic principles of real-time quantitative PCR. Expert Rev. Mol. Diagn. 2005; 5:209-19.

37. Livak KJ, Schmittgen TD. Analysis of relative gene expression data using real-time quantitative PCR and the 2(-Delta Delta C (T)) Method. Methods. 2001; $25: 402-8$. 